\title{
An evaluation of two new haemagglutination tests for the rapid diagnosis of autoimmune thyroid diseases
}

\author{
I. CAYZER, S. R. CHALMERS, D. DONIACH ${ }^{1}$, AND G. SWANA 1 \\ From The Wellcome Research Laboratories, Beckenham, Kent BR3 $3 B S$ and the ${ }^{1}$ Department of \\ Immunology, Middlesex Hospital Medical School, London W1, UK
}

SUMMARY Two haemagglutination tests using preserved turkey erythrocytes are described for the detection of thyroglobulin and microsomal antibodies, respectively. Comparative studies with the more traditional sheep cell techniques show good correlation of titres when testing sera from patients with autoimmune thyroid disorders.

Antibodies to thyroglobulin were first detected by a haemagglutination technique using fresh sheep cells treated with tannic acid (Witebsky and Rose, 1956). The technique was modified (Fulthorpe et al., 1961) using formalin as a preservative to improve the stability of the reagents. Microsomal antibodies have more traditionally been demonstrated by either complement fixation tests or immunofluorescence. More recently, microsomal activity has also been demonstrated by haemagglutination (Fujita and Yamada, 1970) using sheep cells coated with human thyroid microsomal proteins isolated from thyroid glands. Although sheep cells have been used reliably for many years, the use of avian cells as the carrier particle would seem to offer advantages of speed and specificity as demonstrated by their application to other HA systems (Sequeira and Eldridge, 1973; Cayzer et al., 1974).

The present paper describes the production and evaluation of HA tests for the detection of thyroglobulin and microsomal antibodies using turkey in preference to sheep erythrocytes. Both techniques proved easy to perform and read, giving results within one hour.

\section{Material and methods}

\section{CELLS}

Turkey erythrocytes were obtained by collecting blood in Alsevers solution and washing in saline by repeated centrifugation. The treatment of the cells with formaldehyde followed essentially the method described by Sequeira and Eldridge (1973). Cells pre-

Received for publication 5 June 1978 pared by this technique may be stored as a $10 \%$ suspension in saline containing $0.1 \%$ sodium azide at $4^{\circ} \mathrm{C}$ without deterioration for up to six months.

THYROGLOBULIN

The thyroglobulin for cell sensitisation was isolated from human thyroids by fractionation of a saline extract with ammonium sulphate (Derrien et al., 1948). Excess ammonium sulphate was removed from the partially purified thyroglobulin by dialysis against distilled water. The final preparation was stored frozen until required for sensitisation.

\section{MICROSOMAL ANTIGEN}

Thyroid glands taken from patients with Graves disease were immediately frozen and stored until required. The frozen glands were finely sliced with a scalpel, suspended in $0.15 \mathrm{M} \mathrm{KCl}$, and homogenised in a Waring blender. The microsomes were separated from other cell debris by differential centrifugation using a modification of the technique described by Amino et al. (1976). After sonication to obtain a soluble microsomal fraction the antigen was stored frozen until required for sensitisation.

\section{CELL SENSITISATION}

The formaldehyde-preserved cells were treated with tannic acid and then sensitised with either the thyroglobulin or microsomal antigen preparation. The levels of antigen that were required for sensitisation were determined by preliminary experiments covering a range of different antigen concentrations. The optimum proportions of cells and antigens were those which gave maximum sentivity when titrated against sera known to contain the corresponding 
antibodies, while at the same time retaining clarity of sedimentation patterns.

Unsensitised 'control' cells were prepared in the same manner, omitting the procedure of antigen sensitisation.

For long-term stability, test and control cells were preserved by lyophilisation.

\section{SAMPLE DILUENTS}

\section{Thyroglobulin}

The diluent used for titrating serum samples to be tested with the thyroglobulin-coated cells was isotonic saline containing $1 \%$ normal turkey serum.

\section{Microsome}

In addition to normal turkey serum the microsomal cell diluent contained $0.1 \mathrm{mg} / \mathrm{ml}$ of a preparation of human thyroglobulin.

\section{TEST PROCEDURES}

Both haemagglutination tests were carried out using microtitration apparatus with rigid U-welled plates. For the thyroglobulin HA test, unheated serum samples were titrated in doubling dilutions using standard $0.025 \mathrm{ml}$ volumes starting at a dilution of
1:10. To each $0.025 \mathrm{ml}$ of diluted serum was added $0.025 \mathrm{ml}$ of sensitised cells. A control for each serum was included at a dilution of $1: 10$ by adding 0.025 $\mathrm{ml}$ of unsensitised cells. The microsomal HA test was performed by making fourfold dilutions of serum 7 inactivated at $56^{\circ} \mathrm{C}$ for 30 minutes, starting at a 등 dilution of $1: 100$. To each $0.075 \mathrm{ml}$ of diluted serum was added $0.025 \mathrm{ml}$ of sensitised cells. Similarly, a control for each serum using unsensitised cells was included at the 1:100 dilution level. To evaluate the sensitivity and specificity of the two tests, samples were also tested by established, commercially available sheep cell reagents (Thyroglobulin Haemagglutination Test Kit from Wellcome Reagents, 응 Beckenham, Kent; Microsome HA prepared by $\dot{\omega}$ Fujizoki Pharmaceutical Co Ltd, Japan).

The Microsome HA test was also compared with $\vec{N}$ the indirect immunofluorescence technique, using $\overrightarrow{\vec{A}}$ thyrotoxic thyroid glands as substrate. Test sera $\vec{\nabla}$ were applied for 20 minutes at room temperature $\circ$ followed by anti-human-Fab/FITC conjugate with $2 \times 20$ minute washes before and after the conjugate. Positive results obtained with undiluted test sera were subsequently titrated using serial serum dilutions starting at $1: 10$.

A little over 400 test samples were examined by the

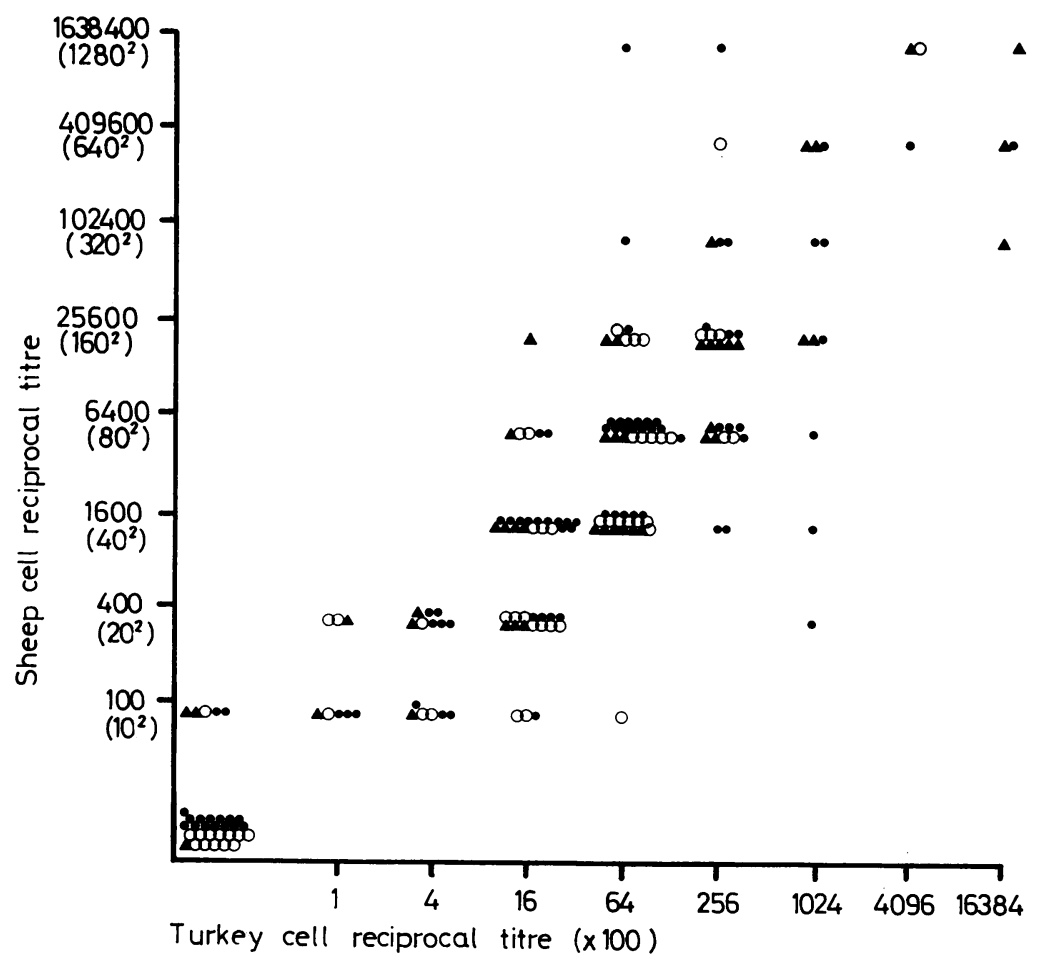

Fig. 1 Comparison of turkey and sheep cell haemagglutination titres for thyroglobulin antibody in 158 sera: Hashimoto $(\mathbf{\Delta}) ;$ myxoedema $(\mathbf{O})$; thyrotoxicosis $(\bigcirc)$. 


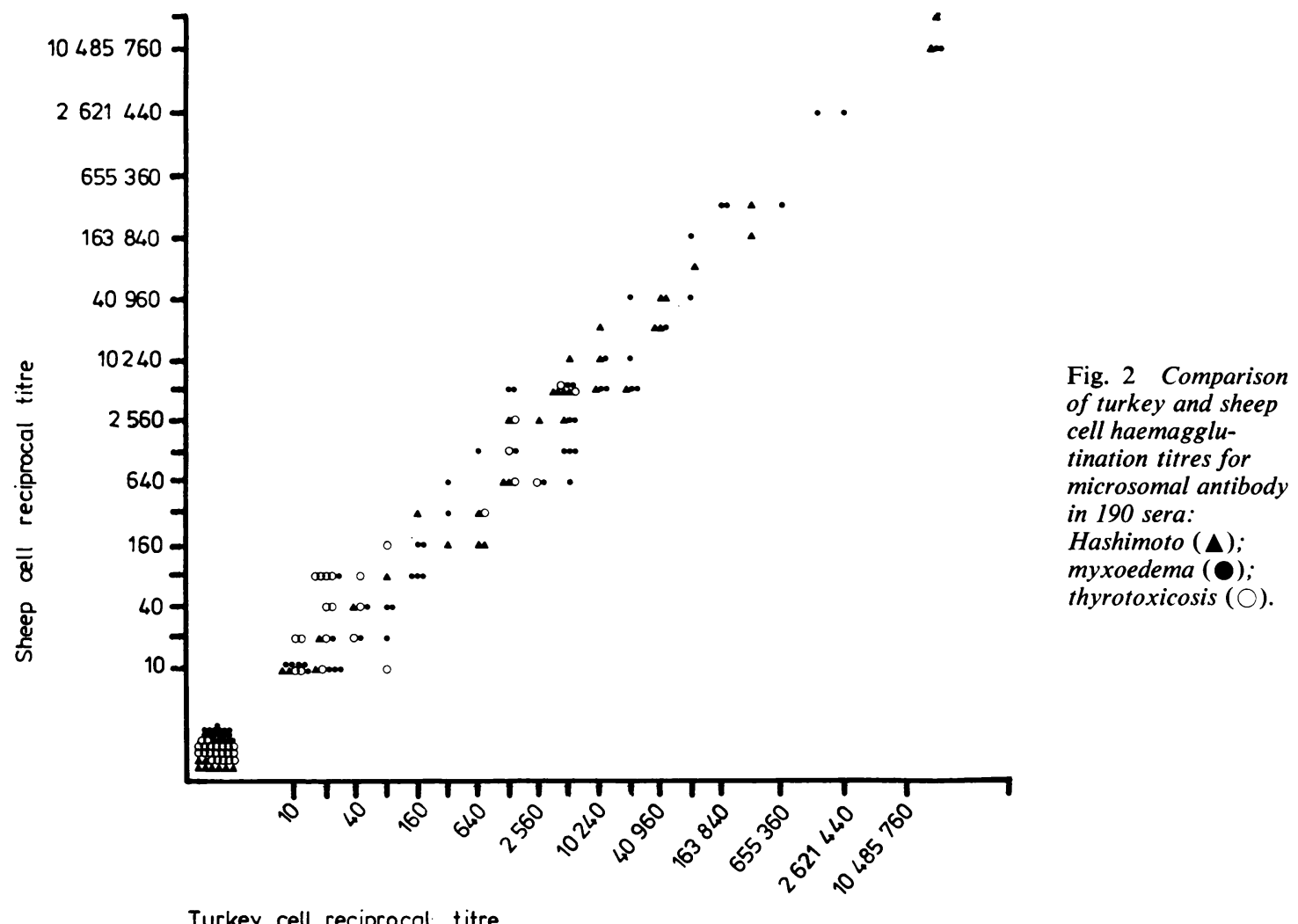

above methods. The samples were of the following origin:

43 sera from patients diagnosed as goitrous thyroiditis (Hashimoto's disease);

70 sera from patients with atrophic thyroiditis (myxoedema);

45 sera from patients with thyrotoxicosis (Graves/

Basedow disease);

32 miscellaneous sera from patients with various autoimmune thyroid disorders (tested by the microsomal HA systems only); and

190 sera from normal blood donors tested as controls.

\section{Results}

Both turkey cell systems correlated well with commercially available sheep cell tests. Figure 1 shows the results of the thyroglobulin titrations comparing the turkey cell method with the sheep cell technique of Fulthorpe.

The titration systems were identical for both reagents, although the two tests were performed on separate occasions in different laboratories. Sera that gave titres in excess of 1:5120 were retested at higher dilutions to ensure a quantitative result.

Satisfactory agreement was also found when comparing the microsomal turkey cells with the Fujizoki sheep cell haemagglutination test kit (Fig. 2).

The latter method was performed according to the manufacturer's instructions using cells freshly reconstituted on the day of test. The results are expressed as the (square root) ${ }^{2}$ of the total reaction volume in the microtitre well. We have preferred to report our results on the turkey cell test as the dilution of the serum before the addition of cells.

There was good correlation between cytoplasmic immunofluorescence and microsomal haemagglutination titres, taking into account the 100 -fold greater sensitivity of the HA test.

The comparison between immunofluorescence and microsomal HA was performed on a small selected group of samples covering a wide range of antibody titres. The correlation between the two test systems is shown in Fig. 3 and shows good agreement at all levels. 


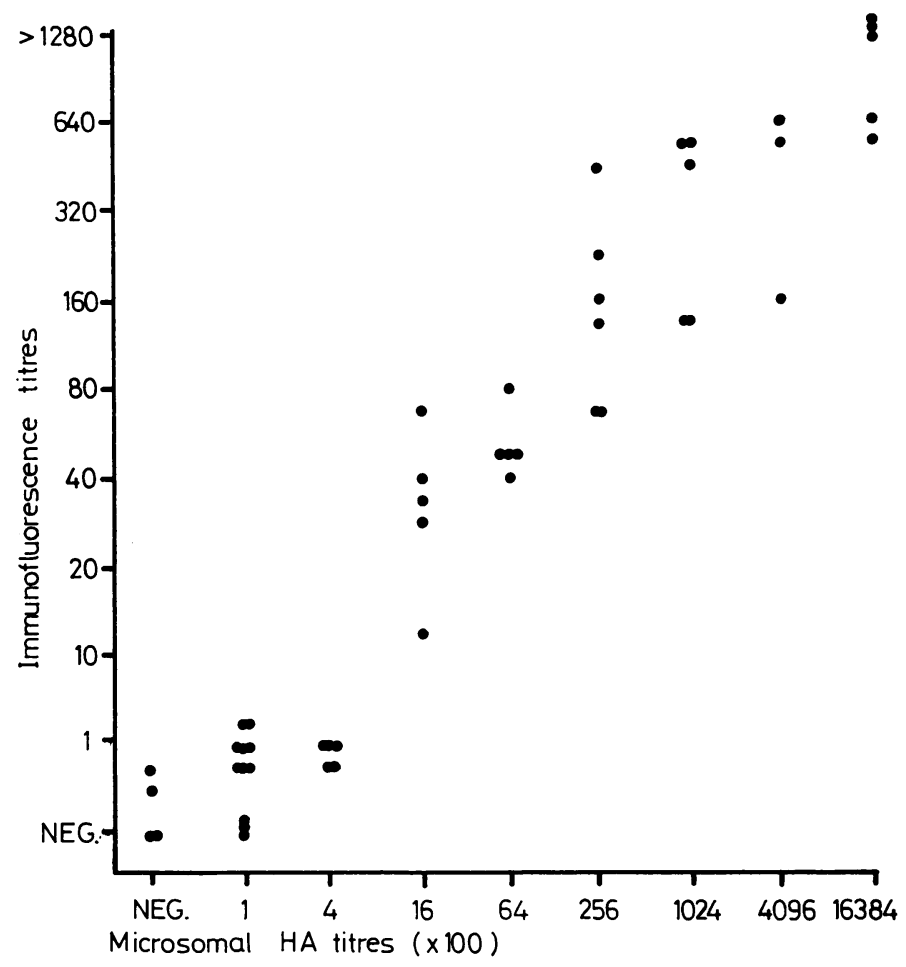

Fig. 3 Correlation between turkey cell haemagglutination and immunofluorescence for microsomal antibody.

Both test systems gave negative results with the majority of normal donors tested. The positive results obtained were generally of low titre, as might be expected in a small random population (Table).

Table Positive results obtained with samples from 190 blood donors

\begin{tabular}{llllll}
\hline Thyroglobulin titres & $<1: 10$ & $1: 10$ & $1: 20$ & $1: 160$ & $1: 640$ \\
No. of sera & 173 & 1 & 4 & 1 & 1 \\
Microsomal titres & $<1: 100$ & $1: 100$ & $1: 400$ & $1: 1600$ & \\
No. of sera & 177 & 2 & 8 & 3 &
\end{tabular}

Among the 16 positive sera (8.5\%), nine contained microsomal antibody only, three thyroglobulin antibody only, and four contained both antibodies.

\section{Discussion}

The thyroglobulin haemagglutination test has for many years been accepted as a simple reliable system for the detection of thyroglobulin antibodies. When used in conjunction with the more recently developed microsomal HA test system, results give useful predictive evidence of thyroid dysfunction in patients with a wide range of autoimmune diseases. The application of turkey cells to passive HA tests has considerably reduced both the incidence of non-specific agglutination and the time taken for the cells to sediment, permitting results to be read in less than one hour. These factors have been used to good advantage in both of the test systems described. The incidence of nonspecific results due to turkey cell agglutinins reacting with unsensitised control cells was less than $1 \%$ when a normal population of blood donors was tested. However the number of nonspecific reactions increased dramatically when sera were tested that were not clear and free from bacterial contamination.

During the preparation of microsomal antigen for cell sensitisation thyroglobulin is often carried over at the same time. The resultant reagent is very likely to give false-positive results with sera containing high-titre antibodies to thyroglobulin. To overcome this difficulty, free thyroglobulin has been added to the microsomal HA diluent.

Although the number of normal donors tested was small, the frequency of positive results (microsomal $7 \%$, thyroglobulin $4 \%$ correlates well with data available on the prevalence of thyroid antibodies in the normal population (Tunbridge et al., 1977). When comparing the titres observed in the three autoimmune thyroid disorders studied, the expected 
spread of results was found. Approximately $45 \%$ of all Hashimoto sera had high titres (in excess of $1: 5120$ ) for thyroglobulin antibodies whereas only $5 \%$ of thyrotoxic patients reached such levels. With both microsomal and thyroglobulin tests the sera from the thyrotoxic patients gave the highest proportion of negative results among the samples from patients with known thyroid disease.

\section{References}

Amino, N., Hagen, S. R., Yamada, N., and Refetoff, S. (1976). Measurement of circulating thyroid microsomal antibodies by the tanned red cell haemagglutination technique: its usefulness in the diagnosis of autoimmune thyroid diseases. Clinical Endocrinology, 5, 115125.

Cayzer, I., Dane, D. S., Cameron, C. H., and Denning, J. V. (1974). A rapid haemagglutination test for hepatitis-B antigen. Lancet, 1, 947-949.

Derrien, Y., Michel, R., and Roche, J. (1948). Recherches sur la préparation et les propriétés de la thyroglobuline pure. I. Biochimica et Biophysica Acta, 2, 454-470.
Fujita, K., and Yamada, N. (1970). Haemagglutination test utilizing the microsomal antigen from thyroid epithelial cells. Clinical Pathology (Japan), 18, 213-218.

Fulthorpe, A. J., Roitt, I. M., Doniach, D., and Couchman, K. (1961). A stable sheep cell preparation for detecting thyroglobulin autoantibodies and its clinical applications. Journal of Clinical Pathology, 14, 645-660.

Sequeira, P. J. L., and Eldridge, A. E. (1973). Treponemal haemagglutination test. British Journal of Venereal Diseases, 49, 242-248.

Tunbridge, W. M. G., Evered, D. C., Hall, R., Appleton, D., Brewis, M., Clark, F., Grimley Evans, J., Young, E., Bird, T., and Smith, P. A. (1977). The spectrum of thyroid disease in a community: the Whickham survey. Clinical Endocrinology, 7, 481-493.

Witebsky, E., and Rose, N. R. (1956). Studies on organ specificity. IV. Production of rabbit thyroid antibodies in the rabbit. Journal of Immunology, 76, 408-416.

Requests for reprints to: I. Cayzer, Wellcome Research Laboratories, Beckenham, Kent BH3 3BS 